\title{
Conducting trials on corticosteroid dosing for respiratory failure in the last paradise
}

\author{
Nobuaki Shimeil
}

\begin{abstract}
It is interesting to find that Japanese clinicians continue to hesitate to change their practice even after accumulating evidence for the inefficacy of high-dose corticosteroid for ARDS in the Letters to the Editor discussion. Given the widespread use of the therapy even for other categories of acute hypoxemic respiratory failure with diffuse alveolar damage represented by acute exacerbation of interstitial pneumonia, Japan is the last part of the world in which efficacy of corticosteroid dosing (including pulse therapy) is assessed in those patients if they wish to continue this trend.
\end{abstract}

\section{Text}

I read with great interest the Letter to the Editor from Meduri et al. [1] for the English version of the "Clinical practice guidelines for the management of adult patients with ARDS" published recently in the Journal of Intensive Care [2] and the reply from the authors [1].

Inclusion of an old randomized controlled trial that investigated high dose of methylprednisolone therapy $(120 \mathrm{mg} / \mathrm{kg}$ over $24 \mathrm{~h})$ [3], which is termed "methylprednisolone pulse therapy," was discussed. It appears that the practice and scientific arguments have been forgotten from Western countries owing to the negative trials conducted approximately two decades ago.

Interestingly, however, the Japanese guideline on acute respiratory distress syndrome (ARDS) management is unable to ignore the therapy, and in fact, Japanese clinical practice appears to adhere that according to a nationwide survey [4]. It would be interesting to know why Japanese clinicians continue to hesitate to change their practice even after a recent publication from a Japanese hospital showing the potential harm of pulse therapy, which was found to be significantly associated with higher mortality and a reduction in the number of ventilator-free days [5].

Moreover, routine use of pulse therapy for acute exacerbation of interstitial pneumonia continues in

Correspondence: shime@koto.kpu-m.ac.jp

Department of Emergency and Critical Care Medicine, Postgraduate School of Medical Science, Hiroshima University, 1-2-3 Kasumi, Minami-ku, Hiroshima 734-8551, Japan
Japan without robust evidence for its use. No studies have shown clinical benefit in using high-dose corticosteroids in patients with acute exacerbation of idiopathic pulmonary fibrosis (a more severe form of interstitial pneumonia) [6, 7]. Although acute exacerbation of interstitial pneumonia is a distinct disease category and is not necessarily associated with diffuse alveolar damage, there is undoubtedly an option for extrapolating the potential beneficial effect and safety of lower-dose corticosteroid therapy, as suggested by Meduri et al., [1] for the difficult-to-treat disease.

Japan is probably the last Galapagos paradise in the world in which assessment of the efficacy of corticosteroid dosing (including pulse therapy) in patients with various categories of acute hypoxemic respiratory failure with diffused alveolar damage (such as ARDS or acute exacerbation of interstitial pneumonia) can be done. Future clinical trials by Japanese clinicians should be conducted if they continue staying in the paradise.

\section{Acknowledgments}

The author thanks Arshad Makhdum, PhD, from the Edanz Group (https://www.edanzediting.co.jp) for editing a draft of this manuscript.

\section{Funding}

This work was supported by KAKENHI Grants from the Japan Society for the Promotion of Science (JSPS) (Numbers JP 17 K11573).

\section{Availability of data and materials}

Data sharing not applicable to this article as no datasets were generated or analyzed during the current study.

\section{Author's contribution}

NS solely contributed to this work. The author read and approved the final manuscript. 
Ethics approval and consent to participate

Not applicable.

\section{Consent for publication}

Not applicable.

\section{Competing interests}

The author declares that he has no competing interests.

\section{Publisher's Note}

Springer Nature remains neutral with regard to jurisdictional claims in published maps and institutional affiliations.

Received: 7 October 2018 Accepted: 13 November 2018

Published online: 20 November 2018

\section{References}

1. Meduri GU, Siemieniuk RAC, Ness RA, Seyler SJ. Prolonged low-dose methylprednisolone treatment is highly effective in reducing duration of mechanical ventilation and mortality in patients with ARDS. J Intensive Care. 2018;6:53.

2. Hashimoto S, Sanui M, Egi M, Ohshimo S, Shiotsuka J, Seo R, Tanaka R, Tanaka Y, Norisue Y, Hayashi Y, et al. The clinical practice guideline for the management of ARDS in Japan. J Intensive Care. 2017;5(1):50.

3. Bernard GR, Luce JM, Sprung CL, Rinaldo JE, Tate RM, Sibbald WJ, Kariman K, Higgins S, Bradley R, Metz CA, et al. High-dose corticosteroids in patients with the adult respiratory distress syndrome. N Engl J Med. 1987;317(25):1565-70.

4. Tasaka S, Tatsumi K, On behalf of the Assembly of Pulmonary Circulation and Lung Injury, the Japanese Respiratory Society. Clinical practice of acute respiratory distress syndrome in Japan: a nationwide survey and scientific evidences. Respir Investig. 2017;55(4):257-63.

5. Takaki M, Ichikado K, Kawamura K, Gushima Y, Suga M. The negative effect of initial high-dose methylprednisolone and tapering regimen for acute respiratory distress syndrome: a retrospective propensity matched cohort study. Crit Care. 2017;21(1):135.

6. Juarez MM, Chan AL, Norris AG, Morrissey BM, Albertson TE. Acute exacerbation of idiopathic pulmonary fibrosis - a review of current and novel pharmacotherapies. J Thorac Dis. 2015;7(3):499-519.

7. Papiris SA, Manali ED, Kolilekas L, Triantafillidou C, Tsangaris I, Kagouridis K. Steroids in idiopathic pulmonary fibrosis acute exacerbation: defenders or killers? Am J Respir Crit Care Med. 2012;185:587-8.

Ready to submit your research? Choose BMC and benefit from:

- fast, convenient online submission

- thorough peer review by experienced researchers in your field

- rapid publication on acceptance

- support for research data, including large and complex data types

- gold Open Access which fosters wider collaboration and increased citations

- maximum visibility for your research: over $100 \mathrm{M}$ website views per year

At $\mathrm{BMC}$, research is always in progress.

Learn more biomedcentral.com/submissions 